Article

\title{
Diversity vs. Pluralism: Reflections on the Current Situation in the United States
}

\author{
James V. Spickard \\ Department of Sociology \& Anthropology, University of Redlands, 1200 Colton Avenue, Redlands, CA 92373, \\ USA; jim_spickard@redlands.edu
}

Received: 5 August 2017; Accepted: 17 August 2017; Published: 28 August 2017

\begin{abstract}
The United States has considerable religious and ethnic diversity; it has not always embraced pluralism. Known as "a nation of immigrants", religion has often been seen as a way to integrate newcomers into its national project. That may have worked for European immigrants, who could become 'White'; it has not worked so well for other ethnic migrants, who could not. The result is a diverse intersectionality that as the present moment is a source of significant religious, ethnic, and political division. Are calls for a vaguely defined "pluralism" enough? No, because deeper social factors are at work. These include increasing economic inequality, a complex split between socio-economic elites and the rest of the population, and shifts in the nature of the religious field. The latter include increased religious individualism, individually oriented prosperity theology, and a sectarian turn among American Evangelicals. Such factors make any simple call for pluralist engagement at best naïve. It is an open question whether or how social unity might be sufficiently reforged.
\end{abstract}

Keywords: diversity; pluralism; immigration; race; inequality; global economy; United States; civil religion

\section{Introduction}

This special issue focuses on "religious diversity" and "religious pluralism" in various parts of the contemporary world. These terms are both familiar and fraught. In common parlance, "diversity" is usually seen as a matter of description: distinct kinds of people living cheek by jowl, interacting or not, divided by religion, race, ethnicity, sexual orientation, political allegiance, or whatever brute empirical distinction they (or others) draw between them. "Pluralism", on the other hand, is a moral term. It is a way to handle diversity by turning separations into a positive way for different people to connect with one another. As Diana Eck, the director of Harvard's "Pluralism Project", put it (Eck n.d.b),

Pluralism is not diversity alone, but the energetic engagement with diversity ... [It] is not just tolerance, but the active seeking of understanding across lines of difference ... [It] is the encounter of commitments ... The language of pluralism is that of dialogue and encounter, give and take, criticism and self-criticism ... Dialogue does not mean everyone at the "table" will agree with one another. Pluralism involves the commitment to being at the table—with one's commitments.

If diversity is a fact, then pluralism is an achievement. It is a way for social democracies to maintain their liberal commitments in the fact of global economic ties, mass migration, and demographic change. It is not the only possible response to such pressures, but it has the merit of balancing social unity with the right of individuals to "be themselves"-whatever that vague phrase means in our increasingly multi-cultural world.

The question is: Is this possible? What does it take to turn diversity into pluralism? What forces get in the way? The United States provides a useful case study, not only because it is so religiously 
and ethnically diverse but because it has wrestled since its beginning with how to forge unity out of differences. Sometimes it has succeeded, sometimes not. The pattern of its successes and failures can tell us something about how diversity and pluralism really work.

\section{Religious Diversity}

We'll start with religious diversity. What does that diversity look like? The world has a lot of it, and it is a lot more obvious now than it was 50 years ago. Much of it stems from recent migrations; humans have always been a traveling lot, and they bring their religions with them. Economic migrants seeking opportunities far from their homelands, political refugees fleeing death or imprisonment, religious missionaries out to win the world for their faiths-these people are now found everywhere. Yes, the Roman Empire mixed peoples from all over the Mediterranean, Chinese fleets and traders spanned the Asian world and perhaps beyond, African Muslims rode to Mecca, while other Africans were sent abroad in chains in the African diaspora that so shaped our present world (Rodney 1974).

Yet our era is qualitatively different. It is not just the number of people on the go, nor their reasons, though these matter. It is the fact that they are going everywhere at once, in all directions, even as they remain connected with all the places that they have been. Cheap, swift travel, multiple communications technologies, and an interconnected world financial system have figuratively shrunk our networked globe. Massive cross-border movement brings disparate peoples together. Diversity-including religious diversity—is the result.

\subsection{Sociological Approaches}

Sociologists of religion have approached this phenomenon in several ways. For example, two major turn-of-the-century research projects described a series of American congregations dominated by what scholars call "the new immigrants": East and South Asians, Latinos, Caribbeans, Africans, and others (Warner and Wittner 1998; Ebaugh and Chafetz 2000). The authors showed how these immigrants used religion to ease their transition to their new country. This approach corresponds to what historian Paul Spickard called "the Ellis Island model"—a term derived from late-nineteenth and early-twentieth century European immigration to the U.S., much of which came through the Ellis Island Federal Immigration Station in New York Harbor (Spickard 2007, p. xvii).

The Ellis Island model sees migrants shedding their old-country identities as they become Americans-and religion helps them do so. The 19th-century American Catholic Church set up ethnic parishes to ease migrants' transition to their new land while keeping them Catholic. Various Protestant groups formed ethnic denominations: Swedish, Norwegian, and German Lutherans, German and Swedish Baptists, and so on. American religion's dominant organizational form-the local congregation-gave newcomers face-to-face contact with others like them as they adjusted to their new surroundings. More than just religious bodies, these became mutual aid societies, sources of emotional support, and reminders of the 'old world'. They ultimately helped their members and above all members' children and grandchildren shift their national identities. By the 1950s, Will Herberg could write about American religion as a process by which various immigrant peoples become unhyphenated Protestants, Catholics, or Jews (Herberg 1955).

In this model, religious diversity does not become religious pluralism, in Eck's sense of "seeking understanding across lines of difference" (Eck n.d.a). Instead, public religious difference fades into private irrelevance. As President-elect Dwight Eisenhauer remarked in 1952, "our Government has no sense unless it is founded on a deeply felt religious faith, and I don't care what it is" (Eisenhower 1952). Wearing religion lightly makes social unity possible.

On the positive side, the Ellis Island model describes rather well the process by which late 19th-century European immigrants turned themselves into White Americans. It is less successful at describing the situation of non-White immigrants, including those 'immigrants' who came involuntarily as slaves. The Middle Passage and the fire of slavery stripped away the differences between the Yoruba, Fon, Ibo, Ewe, Akan, and so forth, but it made them Black, not White. Native 
Americans were shunted to poverty-struck reservations and left out of the body politic. Chinese exclusion, Japanese internment, and so on kept 'Asians' separate. The fact that Gary Locke, America's first Chinese-American state governor, got multiple death threats during his term of office was not a result of his policies; it was the color of his skin.

Sociologists have explored several other patterns of religious diversity, two of which are relevant here. Afe Adogame and I have labelled one of these "religious cacophony" (Spickard and Adogame 2010, pp. 12-13). This is the side-by-side presence of multiple religious groups that have very little to do with one another. Urban ecologist Greg Smith's 2000 survey of the Newham area of east London, for example, found over 300 religious groups using 104 different buildings for their services (Smith and Kulothungan 2006). The majority were Christian-some $60 \%$ - but most of these were small Pentecostal groups that catered to African, Caribbean, and Latin American migrants. There were 22 mosques, along with numerous congregations serving at least ten other major religious groupings (Hindus, Jews, Sikhs, Buddhists, and so on).

A late-1990s walk through this neighborhood produced some striking juxtapositions (Smith 1999a, 1999b). For example, the Calvary Charismatic Baptist Church (Caribbean Pentecostal) on Barking Road stood next door to the Canning Town Muslim Trust-a mosque that occupied what had previously been the local synagogue. A betting shop flanked the mosque on the other side. Three blocks farther east was Glory House, a charismatic prosperity-gospel church, whose multi-ethnic congregation had a multi-national African leadership. Their building was once a mainline Christian church, then it became a shop. Then it became a church again.

Smith pointed out that this area's religious vitality "is in notable contrast to recent national trends in the UK" (Smith 2000, p. 23). Ninety-four of Newham's religious bodies were founded since 1971—and the proportion was higher for the Pentecostal, Hindu, Muslim, and Sikh groups that most served immigrants. Unlike the older British denominations, "for the most part, these new faith communities have operated as refuges from the troubles of wider society rather than as bases for engagement with it".

Here, diversity does not become pluralism; religions remain diverse. Groups live together but they do not interact. Cacophony indeed.

A third pattern involves religious bi-localism. Here, people participate in two religious communities simultaneously - the one from which they emigrated and the one where they currently live. Cheap phone service, air travel, and the Internet let people play important roles in both locales. Peggy Levitt studied one such Dominican immigrant community in Boston, which was able to integrate into the U.S. while simultaneously maintaining close ties to the Dominican village of Miraflores, from which they came (Levitt 2001). They could, and did, participate in parish activities in both places, down to the details of gossip and social pressure that are so typical of local church life. They did not just send money, though economic remittances were important. Equally in play were what Levitt calls "social remittances": the exchange of ideas, practices, and even identities that shifted the Dominican parish's sense of itself. These shifts ran both ways, from Miraflores to Boston and back again; both places were changed.

Levitt's later work has explored other transnational patterns, including multi-local ones (Levitt 2007). This, too, does not necessarily amount to religious pluralism. Though Levitt presents a favorable picture of "religious global citizens", these are but one way in which people handle transnational 'residence'. Like Eck's pluralism, the tolerant acceptance of others is an achievement for individuals who take their own religions seriously while being open to living with others. More often, people either take their religions less seriously or retreat into sectarian enclaves. Neither of these supports the kind of pluralism that Eck recommends.

\subsection{American Religious Diversity}

There is no question that immigration has increased America's religious diversity. It is more questionable whether this amounts to the "radical change" that Eck's Pluralism Project contends 
(Eck n.d.b). Though "there are Islamic centers and mosques, Hindu and Buddhist temples and meditation centers in virtually every major American city" and "the encounter between people of very different religious traditions takes place in the proximity of our own cities and neighborhoods", this does not necessarily result in the level of diversity that Eck claims.

Table 1 contains figures from the 2015 Pew Research Center's "American Religious Landscape" survey of a random sample of over 35,000 American adults (Pew Research Center 2015):

Table 1. Major Religious Traditions in the U.S. in 2014.

\begin{tabular}{|c|c|}
\hline Religious Family & Percent of Population \\
\hline Christian & 70.6 \\
\hline Protestant & 46.5 \\
\hline Evangelical & 25.4 \\
\hline Mainline & 14.7 \\
\hline Historically Black & 6.5 \\
\hline Catholic & 20.8 \\
\hline Orthodox Christian & 0.5 \\
\hline Mormon & 1.6 \\
\hline Jehovah's Witness & 0.8 \\
\hline Other Christian & 0.4 \\
\hline Non-Christian Faiths & 5.9 \\
\hline Jewish & 1.9 \\
\hline Muslim & 0.9 \\
\hline Buddhist & 0.7 \\
\hline Hindu & 0.7 \\
\hline Other world religions ${ }^{1}$ & 0.3 \\
\hline Other faiths ${ }^{1}$ & 1.5 \\
\hline Unaffiliated & 22.8 \\
\hline Atheist & 3.1 \\
\hline Agnostic & 4.0 \\
\hline Nothing in particular & 15.8 \\
\hline Don't know/refused & $\begin{array}{c}0.6 \\
\text { TOTAL: } 100.0\end{array}$ \\
\hline
\end{tabular}

1 "Other world religions" include Sikhs, Baha'is, Taoists, Jains, etc. "Other faiths" include Unitarians, New Age religions, Native American religions, etc.

The first thing to note is that the U.S. has an overwhelmingly Christian population. This is not just true of the $85 \%$ of survey respondents who are native-born; $68 \%$ of the foreign-born (immigrant) adults surveyed identify as Christian, though many more of them are Catholic (39\%) than are Protestant (25\%). About $8 \%$ of the foreign-born are non-Christian, as opposed to $6 \%$ of native-born. Twenty percent of immigrants are religiously unaffiliated, nearly the same as the population at large.

In short, immigration is indeed changing America's religious landscape, just not as much as we might think. Eck's "new pluralism" covers just under $6 \%$ of the population- $4 \%$ if you leave out Jews, who have long been part of the American religious scene.

Second, the most prominent shift in American religious life is from affiliation to non-affiliation. In 1973, just 6.6\% of American adults claimed to have "no religion" (NORC 1973); the figure from the 2007 version of the Pew "Landscape" Survey was 16\%. Eight years later, we get the $22.8 \%$ figure above. If numbers were all that mattered, religious diversity ought to be less of a 'problem' than religious defection, but the size of a social phenomenon does not always dictate its cultural importance.

These numbers are misleading, however, and in two senses. First, there is a lot of diversity within American Christianity, especially Protestantism. For example, the Pew "Landscape" survey divides the Evangelical Protestants into 16 major traditions, each of which is made up of many different groups. Not all are on speaking terms, despite doctrinal similarities. My college town, for example, is home to three different Dutch Reformed churches, from separate denominations, who have little to do with 
each other. There is thus much more diversity than the summary figures lead us to expect. It is merely among Christians, not between Christians and other groups.

At the same time, the "religiously unaffiliated" are mostly not atheists and agnostics; they claim "no religion in particular". That explains the 2010 General Social Survey's report that $21 \%$ of those claiming "no religion" pray at least daily, half of those more than once (NORC 2010). Hout and Fischer traced growing non-affiliation to liberal disgust with Evangelical Protestantism's increased engagement in politics (Hout and Fischer 2002); Putnam and Campbell made the same argument with different and more extensive data (Putnam and Campbell 2010). Claiming "no religion" is thus not so much a statement about one's beliefs as about one's unwillingness to be identified with religious organizations that one does not like.

In sum, the United States is beset by considerable religion and by considerable diversity, albeit most of it Christian. Religion matters here, but the same religion does not matter to everyone.

\section{E Pluribus Unum}

America has wrestled with diversity since its beginnings; it makes sense that our national motto is e pluribus unum: "out of many, one". The U.S. has long embraced a civic nationalism at odds with the ethnic nationalism typical of many parts of Europe (Ignatieff 1993). Mass citizenship ceremonies are commonplace and the idea that people come from all over the earth to become Americans is a source of national pride-even for those who would prefer that all immigrants entered legally and were White.

Despite the Ellis Island myth, however, American immigrants have never all assimilated to the Protestant Anglo-Saxon norm: not racially, not culturally, not religiously. Anti-Catholic agitation spanned the 19th-century and Mormons barely survived persecution. Animosity toward Jews has long been part of the American scene. Religious tolerance worked reasonably well during Eisenhower's 1950s, when denominational religion ruled and sectarians stayed in the background. John Kennedy's 1960 election as the first Catholic president was a high mark, though my childhood Jewish friends had stomachaches all December because school authorities presumed that everyone celebrated Christmas and had trouble imagining that some people did not.

Times have changed. The 1970s growth of the Christian Right and its post-1980 alignment with the Republican Party are well known (Schlozman 2015). American politics have become increasingly sectarian -in the sense that neither religious nor political sectarians recognize the legitimacy of other groups (McGuire 2002, chp. 5). Politics remain religiously split: exit polls from the 2016 Presidential election show that $81 \%$ of White Evangelical Christians voted for the victorious Republican candidate, as compared to only $26 \%$ of both Hispanic Catholics and the religiously unaffiliated, $24 \%$ of Jews, and $29 \%$ of people of other faiths (Smith and Martínez 2016). Adherents of two main political parties increasingly dislike and even fear each other, in part on moral grounds (Pew Research Center 2016). Politics are also racially polarized: $58 \%$ of Whites voted Republican, compared to $8 \%$ of Blacks and $29 \%$ of both Hispanics and Asians (Huang et al. 2016). There are also distinct urban vs. rural and economically optimistic vs. economically pessimistic divides. In short, Americans are quite possibly as divided as they have ever been-and religion is one of the main cleavage lines.

How can a coherent society survive such divisions?

There are at least three ways to craft a unified social order, two of which Émile Durkheim uncovered over a century ago (Durkheim 1964). First, we can make sure that everyone is alike: what he called "mechanical solidarity", in which people stick together because of their similarities. In this kind of society, people are connected by common ideas, common rituals, and the common practices of daily life. Religious diversity is acceptable to the degree that religion is lightly held, but not to the degree that it makes people think differently from each other. Thus Herberg's 1950s Jews were never ultra-Orthodox, his Catholics never ultramontane, and his portrayal of Protestantism drew from the Mainline, not the Fundamentalists (Herberg 1955). Little could he see the Evangelical resurgence two decades down the road. 
Herberg was right in noting the strong streak of tolerance in American religious life, and immigration does change the shape of the faiths transplanted here, particularly organizationally (Warner and Wittner 1998; Ebaugh and Chafetz 2000). Yet the underlying issue remains: the Ellis Island solution did not produce social uniformity, neither ethnic nor religious.

Durkheim proposed a second route to social coherence, which he called "organic solidarity". By this he meant the ties that emerge because we all have different jobs, skills, and tastes, and because our complex economy needs these differences to prosper. This complex interconnection typifies the world we live in, even more than it did in Durkheim's day. For one thing, our current division of labor stretches across the globe. Take our clothes: our shirts are sewn in Haiti or Vietnam from cotton grown in Tajikistan or El Salvador mixed with polyester from Venezuela or Iran; they are shipped on Liberian or Indian freighters with international (though skeleton) crews. Only the selling is local and this only if it is not online. Multiply this by all the other parts of our economies and we need each other as we never have before.

Can complex interdependence this reduce the divisions we see before us? Can Americans learn to see their fates as tied up with people quite different from themselves? Durkheim had his doubts. He worried that a complexly interconnected society would give people too few solid connections to avoid social breakdown. How can people feel united, if their only shared idea is the abstract notion that they are all part of a larger, integrated system? He was probably right that people need a closer sense of belonging, though his proposed "intermediary institutions" are likely not be enough to bridge the gap. Eisenhower's "and I don't care what it is" religion clearly wasn't enough, as subsequent decades have shown.

\subsection{American Civil Religion}

The United States provides a third model. Robert Bellah famously described American "civil religion" as a set of concepts, ritual phrases, and ideals that construct a national sense of purpose (Bellah 1967). Civil religion is not henotheism, a term that theologian H. Richard Niebuhr (Niebuhr 1960) used to denote worship of the group itself. It is not worship of a society or a nation, and it is certainly not patriotism. It is, instead, an identity crafted from a common sense of mission, specifically the belief that the United States has an important role to play in the world. Various parts of the national myth support this belief. The U.S. is to be an example to others: "a city on a hill", "a light to the nations". It is to foster democracy, support freedom, and come to the defense of others. It is also supposed to give generously to them-not to make them dependent (in the myth) but to help them stand on their own feet. Bellah ably traced these themes through national texts and teased out those texts' religious overtones.

The American political Left and Right still agree about this "American exceptionalism". They do not, however, agree about what America's specific role ought to be. Right-wingers typically favor promoting capitalism, prosperity, and world order. Left-wingers choose human rights and individual freedoms. The two sides thus support different interventions: the Right supported America's invasion of Iraq to overthrow a cruel dictator; the Left was more interested in invading Afghanistan to aid suppressed women. We can perhaps trace our recent political discord to these competing visions of America's proper role in the world.

Bellah rightly noted that all such national missions are prophetic. Indeed, like the Old Testament prophets, American civil religion calls both government and society to account for their misdeeds as well as demands that they act rightly. "With great power comes great responsibility" was an effective movie line because it resonated so deeply with American culture. To be exceptional, America's national sense of purpose cannot merely be self-serving. To frame this in identity-language, Americans (in this ideology) are the people who are called to serve everyone. The ideals for which America is famous-democracy, freedom, justice-are an unfinished project. Can a country shape its collective identity around helping everyone attain them? 
In this vision, America begins in diversity, but American civil religion is not just a matter of diverse people talking civilly with one another. Civil religion is diversity on a mission. The mission is supposed to bind Americans together in service to the world. This kind of unity is eschatological, embedded in national ideals.

\subsection{Problems}

There are, of course, problems with this. The most obvious is that the United States does not live up to these ideals very well and has never done so consistently. The theft of Native American and Mexican land, multiple invasions of Central American and Caribbean countries, war crimes in Vietnam and Iraq, holding prisoners without charge or trial at Abu Ghraib and Guantanamo prisons; the list is long (Blum 2008). Above all, there is the national stain of two and a half centuries of chattel slavery plus a hundred and fifty more of the continued legal repression of Black Americans through Jim Crow and mass incarceration (Blackmon 2008; Alexander 2010). America's democracy was built on slave power and has never quite escaped its racist origins (Wills 2003).

There, is, however, a second point of worry. American culture has undergone a shift in recent years, away from its quasi-religious collective national mission to a distinctly individualistic economic one. To be blunt about it, America is now the place where people hope to get rich. The United States still sees itself as the land of freedom, but now it is as much freedom to enjoy wealth as it is freedom to do good in the world. Former President George W. Bush didn't actually urge Americans to "go shopping" as a response to the 9/11 terrorist attacks; he did, however, identify America's vibrant economy as the thing that its enemies envy. More significant to religion is the recent growth of prosperity theology. This movement in charismatic Christianity claims that God wants His people to enjoy personal wealth and encourages them to give bountifully to their churches in order to get it (Bowler 2013). Many poor are attracted, in part because they have few other options and in part because it motivates them to work hard in the informal economy (Freston 2014). Have the search for economic enrichment and personal consumption become a core part of the U.S. religious landscape? Durkheim worried about this-not the consumption part so much as the individualism and anomie that he feared would come from treating economic achievement as life's main goal. Bellah worried about the dangers of the America's growing individualistic ways of thinking (Bellah et al. 1985). What do these developments mean for the possibility of an engaged religious pluralism?

Let me turn the screw a bit farther. Several scholars have found evidence of increased religious individualism, particularly in the most economically developed countries. Paul Heelas and Linda Woodhead, for example, traced a shift from theistic religion to what they called "subjective-life" spirituality in Britain and the United States (Heelas and Woodhead 2005). They read the latter as a process of religious individualization, though that may in part be an artifact of their research design (Spickard 2017, pp. 128-30). If religion is individualizing, are we moving toward the situation that Bellah feared: "the logical possibility of more than 235 million American religions, one for each of us" (Bellah et al. 1985, p. 221)? This is diversity on steroids. Is pluralism's engaged dialogue a sufficient answer?

\section{Is Pluralism Enough?}

As Pamela Klassen and Courtney Bender point out, "pluralism" is a normative term. "Pluralism recognizes some kinds of religious interactions and encounters and some kinds of religions (but not others) as normal and natural" (Klassen and Bender 2010, p. 3). It distinguishes between 'good' religion that is open to engaged dialogue and 'bad' religion that is not. As Robert Orsi has noted, this is a long-standing tendency in the study of religion (Orsi 2005, p.183 ff.). Ideologically, it produces an us/them distinction, in which 'we' (the good people) are in favor of dialogue and 'they' (the bad ones) are not. In this view, religious diversity is positive in so far as it provides an opportunity for "understanding across lines of difference" (Eck n.d.a); it is negative only if such understanding is not allowed to occur. 
Pluralism is more than just normative, however; it is also ideologically loaded. To quote Klassen and Bender again, "Pluralism, like the related concepts of secularism and religion, emerged in response to particular challenges in the development of Western liberal democracies" (Klassen and Bender 2010, p. 8). One of those challenges is continued economic inequality-something that liberal democracy was supposed to ameliorate but has failed to do so consistently (Pickett and Wilkinson 2011). Pluralism promotes an interpersonal solution to diversity while diverting attention away from diversity's socio-economic causes. Sociologists from Mannheim to Fairclough have stressed the importance unmasking such slights-of-hand (Mannheim 1970; Fairclough 2014). Any "active engagement with diversity" (Eck n.d.a) requires that we examine diversity's sources, particularly the economic causes of the international migrations that have so many people moving so many directions across the globe, bringing their religions with them.

The primary cause is the emergence of a truly global economy. What used to be a collection of national labor markets has become, of late, much more integrated. At the elite level, corporations now draw talent from many parts of the globe. This is the source of much recent East and South Asian migration, though migrants of Middle Eastern origin also form what the French sociologist Olivier Roy calls a "deterritorialized elite", some of whose members have adopted Islam as a master identity (Roy 2004). Most of the figures in Levitt's 2007 study are at least multi-territorial; with the exception of Roy's Islamists, such transnational elites are the likeliest to affirm a tolerant "religious global citizenship" (Levitt 2007).

The global labor market attracts more than the elite, however. It also encourages non-elites to move from poorer to richer countries. Part of this is push-migration: un- or underemployed people moving from places of poverty to places with greater opportunities. Examples include Mexican, Central American, and Caribbean migration to the U.S., African migration to Europe, and internal E.U. migrants from Eastern European E.U. countries to the U.K., France, Germany, and the Netherlands.

Religiously, Latin American and Caribbean immigration refills U.S. Catholic parishes, though sometimes it creates shared language-based parishes rather than social integration (Hoover 2014). Latinos also form independent Protestant congregations or join the ranks of the religiously unaffiliated (Ghiani 2014). African Pentecostals diversify Europe but their religion does not follow the Ellis Island model, as it does not integrate them into the existing social order (Butticci 2016; Adogame 2013). Polish migrants to the U.K. swell Catholic rolls but bring with them a very different attitude towards the Church than among native Britons. Theirs is a less universalist and more identity-based Catholicism, which becomes a source of social tension (Trzebiatowska 2010).

However, not all labor migration is pushed by poorer countries' circumstances. Neo-liberal capitalism also pulls in cheap labor while simultaneously eroding the richer countries established labor protections. Part-time jobs, outsourcing, casual labor, and the growth of 'independent contractors' all reduce employers' costs and commitments. The growth of what Guy Standing calls "the precariat" surely has religious consequences, though this territory remains little explored (Standing 2011).

Capitalism pushes native workers into the precariat, too. No small part of Americas current political discord comes from a sense of deprivation on the part of a formerly secure White working class that now faces fading industries and unstable labor markets (Pettigrew 2017). It is easy for them to lash out at immigrants, environmental regulations, 'uppity' minorities, and a government that protected the elite during the 2008-2010 economic crash while millions of working people lost their homes (Hochschild 2016). Yes, racism plays a part, particularly in American elections (McElwee and McDaniel 2017), but increased economic inequality also drives political resentment. Such resentment too often seeks scapegoats. It makes it unlikely that people will engage in self-critical dialogue.

That's the point: the call for pluralist "engagement with diversity" works if all sides have a certain level of comfort with their life situations. It takes such comfort to risk self-criticism. Hillary Clinton's campaign comment that half of Donald Trump's supporters belong in "a basket of deplorables" reinforced Trump voters' sense that the internationalist economic elite looks with distain on ordinary people. Those elites have the requisite economic security but much of the world's population does 
not. Eck is right in saying that pluralism is an achievement. It is not, however, just a matter of having enough good will. Parties to the dialogue must feel respected by each other and must not feel that their lives are threatened by forces outside of their control.

Which brings us back to Klassen and Bender's point. "Pluralism" is an ideological construct because it encourages us to ignore the fact that our diversity is rooted in a specific socio-economic situation. It encourages people to think that mere dialogue will bridge differences. Diversity ceases to be a problem when we mitigate its socio-economic causes. Dialogue helps, but it is not enough.

Conflicts of Interest: The author declares no conflict of interest.

\section{References}

Adogame, Afe. 2013. The African Christian Diaspora: New Currents and Emerging Trends in World Christianity. London: Bloomsbury.

Alexander, Michelle. 2010. The New Jim Crow: Mass Incarceration in the Age of Colorblindness. New York: The New Press.

Bellah, Robert N. 1967. Civil Religion in America. Daedalus 96: 1-21. [CrossRef]

Bellah, Robert N., Richard Madsen, William M. Sullivan, Ann Swidler, and Steven M. Tipton. 1985. Habits of the Heart: Individualism and Commitment in American Life. Berkeley: University of California Press.

Blackmon, Douglas A. 2008. Slavery by Another Name: The Re-Enslavement of Black Americans from the Civil War to World War II. New York: Doubleday.

Blum, William. 2008. Killing Hope: U.S. Military and C.I.A. Interventions since World War II-Updated through 2003. Monroe: Common Courage Press.

Bowler, Kate. 2013. Blessed: A History of the American Prosperity Gospel. New York: Oxford University Press.

Butticci, Annalisa. 2016. African Pentecostals in Catholic Europe: The Politics of Presence in the Twenty-First Century. Cambridge: Harvard University Press.

Durkheim, Émile. 1964. The Division of Labor in Society. Translated by George Simpson. New York: Free Press. First published 1893.

Ebaugh, Helen Rose, and Janet Chafetz, eds. 2000. Religion and the New Immigrants: Continuities and Adaptations in Immigrant Congregations. Walnut Creek: Altamira Press.

Eck, Diana L. n.d.a. What Is Pluralism? Available online: http:/ / pluralism.org/what-is-pluralism/ (accessed on 15 July 2017).

Eck, Diana L. n.d.b. Pluralism Project: Mission. Available online: http:/ /pluralism.org/about/our-work/mission/ (accessed on 29 July 2017).

Eisenhower, Dwight. 1952. Text of Eisenhower Speech to the Freedoms Foundation. New York Times, December 23, p. 16.

Fairclough, Norman. 2014. Language and Power, 3rd ed. London: Longman.

Freston, Paul. 2014. Prosperity Theology: A (Largely) Sociological Assessment. Paper presented at the Lausanne Global Consultation on Prosperity Theology, Poverty, and the Gospel, Atibaia, Brazil, March 30-April 3. Available online: https:/ / www.lausanne.org/content/prosperity-theology-a-largelysociological-assessment (accessed on 1 August 2017).

Ghiani, Fatima. 2014. Different Destinations for U.S. Hispanics, Latin Americans Who Leave Catholic Church. Factank: News in the Numbers, Pew Research Center. November 24. Available online: http:/ / www.pewresearch.org/fact-tank/2014/11/24/different-destinations-for-u-s-hispanics-latinamericans-who-leave-catholic-church/ (accessed on 3 August 2017).

Heelas, Paul, and Linda Woodhead. 2005. The Spiritual Revolution: Why Religion Is Giving Way to Spirituality. Oxford: Basil Blackwell.

Herberg, Will. 1955. Protestant, Catholic, Jew: An Essay in American Religious Sociology. Garden City: Doubleday.

Hochschild, Arlie Russell. 2016. Strangers in Their Own Land: Anger and Mourning on the American Right. New York: The New Press.

Hoover, Brett C. 2014. The Shared Parish: Latinos, Anglos, and the Future of U.S. Catholicism. New York: New York University Press. 
Hout, Michael, and Claude S. Fischer. 2002. Why More Americans Have No Religious Preference: Politics and Generations. American Sociological Review 67: 165-90. [CrossRef]

Huang, Jon, Samuel Jacoby, Michael Strickland, and K. K. Lai. 2016. Election 2016: Exit Polls. New York Times, November 8. Available online: https:/ /www.nytimes.com/interactive/2016/11/08/us/politics/electionexit-polls.html (accessed on 31 July 2017).

Ignatieff, Michael. 1993. Blood and Belonging: Journeys into the New Nationalism. New York: Farrar, Strauss, and Giroux.

Klassen, Pamela E., and Courtney Bender. 2010. Habits of Pluralism. In After Pluralism: Reimagining Religious Engagement. Edited by Courtney Bender and Pamela E. Klassen. New York: Columbia University Press, pp. 1-28.

Levitt, Peggy. 2001. The Transnational Villagers. Berkeley: University of California Press.

Levitt, Peggy. 2007. God Needs No Passport: Immigrants and the Changing American Religious Landscape. New York: The New Press.

Mannheim, Karl. 1970. Ideology and Utopia: An Introduction to the Sociology of Knowledge. Translated by Louis Wirth. New York: Harcourt, Brace \& World. First published 1936.

McElwee, Sean, and Jason McDaniel. 2017. Economic Anxiety Didn't Make People Vote Trump, Racism Did. The Nation, May 8. Available online: https:/ / www.thenation.com/article/economic-anxiety-didnt-makepeople-vote-trump-racism-did/ (accessed on 3 August 2017).

McGuire, Meredith B. 2002. Religion: The Social Context, 5th ed. Belmont: Wadsworth.

Niebuhr, H. Richard. 1960. Radical Monotheism and Western Culture, with Supplementary Essays. New York: Harper \& Brothers, Publishers.

National Opinion Research Center (NORC). 1973. General Social Survey. Available online: http://gss.norc.org/ (accessed on 3 August 2017).

National Opinion Research Center (NORC). 2010. General Social Survey. Available online: http://gss.norc.org/ (accessed on 3 August 2017).

Orsi, Robert A. 2005. Between Heaven and Earth: The Religious Worlds People Make and the Scholars Who Study Them. Princeton: Princeton University Press.

Pettigrew, Thomas F. 2017. Social Psychological Perspectives on Trump Supporters. Journal of Social and Political Psychology 5: 107-16. [CrossRef]

Pew Research Center. 2016. Partisanship and Political Animosity. Research Report. Available online: http:/ / assets.pewresearch.org/wp-content/uploads/sites/5/2016/06/06-22-16-Partisanship-andanimosity-release.pdf (accessed on 31 July 2017).

Pew Research Center. 2015. Pew Forum on Religion and Public Life. America's Changing Religious Landscape. Available online: http://www.pewforum.org/2015/05/12/americas-changing-religiouslandscape/ (accessed on 29 July 2017).

Pickett, Kate, and Richard Wilkinson. 2011. The Spirit Level: Why Greater Equality Makes Societies Stronger. London: Bloomsbury Press.

Putnam, Robert D., and David E. Campbell. 2010. American Grace: How Religion Divides and Unites Us. New York: Simon \& Schuster.

Rodney, Walter. 1974. How Europe Underdeveloped Africa. Washington: Howard University Press.

Roy, Olivier. 2004. Globalized Islam: The Search for a New Ummah. New York: Columbia University Press.

Schlozman, Daniel. 2015. How the Christian Right Ended up Transforming American Politics. TPM Cafe, Talking Points Memo. August 25. Available online: http://talkingpointsmemo.com/cafe/brief-history-of-thechristian-right (accessed on 5 August 2017).

Smith, Greg. 1999a. Photo Pilgrimage around Newham [East London]. Paper presented at the International Society for the Sociology of Religion, Leuven, Belgium, July 26-30.

Smith, Greg. 1999b. East London Is No Longer Secular: Religion as a Source of Social Capital in the Regeneration of East London. Rising East: The Journal of East London Studies 4: 124-53.

Smith, Greg. 2000. Global Systems and Religious Diversity in the Inner City-Migrants in the East End of London. International Journal on Multicultural Studies 2: 16-39.

Smith, Greg, and Gladius Kulothungan. 2006. Newham Twenty Years On: Research Report. London: Communities in Transition and CULF. 
Smith, Gregory A., and Jessica Martínez. 2016. How the Faithful Voted: A Preliminary 2016 Analysis. Factank: News in the Numbers, Pew Research Center. November 9. Available online: http:/ / www.pewresearch.org/ fact-tank/2016/11/09/how-the-faithful-voted-a-preliminary-2016-analysis/ (accessed on 31 July 2017).

Spickard, Paul R. 2007. Almost All Aliens: Immigration, Race, and Colonialism in American History and Identity. New York: Routledge.

Spickard, James V. 2017. Alternative Sociologies of Religion: Through Non-Western Eyes. New York: New York University Press.

Spickard, James V., and Afe Adogame. 2010. Africa, the New African Diaspora, and Religious Transnationalism in a Global World. In Religion Crossing Boundaries: Transnational Religious and Social Dynamics in Africa and the New African Diaspora. Edited by Afe Adogame and James V. Spickard. Leiden: E.J. Brill, pp. 1-28.

Standing, Guy. 2011. The Precariat: The New Dangerous Class. London: Bloomsbury Press.

Trzebiatowska, Mara. 2010. The Advent of the 'EasyJet Priest': Dilemmas of Polish Catholic Integration in the UK. Sociology 44: 1055-72. [CrossRef]

R. Stephen Warner, and Judith G. Wittner, eds. 1998. Gatherings in Diaspora: Religious Communities and the New Immigration. Philadelphia: Temple University Press.

Wills, Gary. 2003. Negro President: Jefferson and the Slave Power. New York: Houghton Mifflin Harcourt.

(C) 2017 by the author. Licensee MDPI, Basel, Switzerland. This article is an open access article distributed under the terms and conditions of the Creative Commons Attribution (CC BY) license (http:/ / creativecommons.org/licenses/by/4.0/). 